\title{
ANDERSEN SYNDROME
}

\section{An association of periodic paralysis, cardiac arrhythmia and dysmorphic abnormalities}

\author{
Célia H. Tengan', Antonio C. Antunes', José R. Bauab1, \\ Gilmar F. Prado², Gilberto M. Manzano', Alberto A. Gabbai ${ }^{1}$
}

\begin{abstract}
Andersen syndrome (AS) is a rare disease characterized by the presence of periodic paralysis (PP), cardiac arrhythmia and dysmorphic abnormalities. We report herein the first Brazilian patient presenting AS who also had obesity, obstructive sleep apnea (OSA) and daytime sleepiness. Clinical and genetic evaluation of six family members demonstrated that four had dysmorphic abnormalities but none had PP or cardiac arrhythmia. Sequencing of $K C N J 2$ revealed the R218W mutation in the index patient and her 6-year-old daughter, who presented dysmorphic abnormalities (micrognathia, clinodactyly of fourth and fifth fingers, short stature) and OSA. Three relatives had clinodactyly as the only manifestation but the R218W mutation was absent, suggesting that this characteristic may be influenced by another gene. OSA accompanied by dysmorphic features may be related to AS.
\end{abstract}

KEY WORDS: periodic paralysis, cardiac arrhythmia, dysmorphism, obstructive sleep apnea.

\begin{abstract}
Síndrome de Andersen: uma associação de paralisia periódica com arritmia cardíaca e alterações dismórficas

RESUMO - A síndrome de Andersen (SA) é doença rara caracterizada pela presença de paralisia periódica (PP), arritmia cardíaca e anormalidades dismórficas. Relatamos o primeiro paciente brasileiro apresentando SA, e que também apresenta obesidade e apnéia obstrutiva do sono (AOS). Avaliações clínica e genética de seis familiares demonstraram que quatro apresentavam alterações dismórficas mas nenhum tinha PP ou arritmia cardíaca. O sequenciamento do gene KCNJ2 revelou a mutação R218W no paciente índex e sua filha de 6 anos, que apresentava alterações dismórficas (micrognatia, clinodactilia do quarto e quinto dedos, baixa estatura) e AOS. Três familiares tinham clinodactilia como única manifestação mas a mutação R218W estava ausente, sugerindo que esta característica seja influenciada por outro gene. A AOS associada a alterações dismórficas pode estar relacionada à SA.
\end{abstract}

PALAVRAS-CHAVE: paralisia periódica, arritmia cardíaca, dismorfismo, apnéia obstrutiva do sono.

Periodic paralyses are a very interesting group of diseases mainly characterized by recurrent episodes of flaccid paralysis affecting upper and/or lower limbs. They are classified in hypokalemic and hyperkalemic based on serum potassium levels during attacks of weakness and response to potassium administration? Episodic weakness is secondary to abnormalities in sarcolemmal excitability due to dysfunctional ion channels. Periodic paralyses are included in the group of disorders called channelopathies and mutations were identified in genes coding for sodium (SCN4A) $)^{2,3}$, calcium (CACNIAS) $)^{4,5}$ and potassium $(K C N J 2)^{6}$ channels.
A distinct form of periodic paralysis (PP), Andersen syndrome (AS), was recently recognized and characterized by the presence of periodic paralysis (PP), cardiac arrhythmia (prolonged QT interval or ventricular arrhythmia) and dysmorphic abnomalities ${ }^{7,8}$. This disease is caused by a dysfunction of the inward-rectifying potassium channel Kir2.1, and several mutations have already been identified in the gene coding for this channel, $K C N J 2^{6}$. The presence of developmental abnormalities is the most striking difference from other forms of PP, but the contribution of Kir2.1 in bone development remains unexplained.

\footnotetext{
${ }^{1}$ Division of Neurology, Department of Neurology and Neurosurgery, Universidade Federal de São Paulo, SP, Brazil (UNIFESP); ${ }^{2}$ Department of Medicine, UNIFESP. Supported by Sociedade Paulista para o Desenvolvimento da Medicina (FADA - Fundo de Auxílio a Docentes e Alunos). FAPESP and CNPq supported Dr. CHT.
}

Received 24 November 2005, received in final form 13 February 2006. Accepted 8 April 2006. 
We re portherein a Brazilian patient with AS and obstructive sleep apnea (OSA). To the best of our knowledge, this is the first report of AS in Brazil.

\section{CASE}

A 33-year-old Brazilian man complained of episodic weakness since age of five, with normal muscle strength between attacks. The episodes of weakness had variable duration (from minutes to hours) and start ed during re st after a period of physical exercise, such as playing soccer, carrying heavy weights. Continuous exercise of mild intensity, such as flexion and extension of the knees, improved muscle strength during crisis. The affected muscles were mostly from the legs but with time, arms were also affected. The frequency of attacks varied according to intensity and duration of physical exercise. During cold weather, the attacks were usually more frequent, being everyday in the worst periods. Other provocative factors, such as fasting or carbohydrate intake, were not re ported. The patient did not complain of muscle pain or cramps. At 13 years of age, he started with difficulty in climbing stairs even between attacks. He continued perf o rming daily activities though he had developed an inter-attack proximal weakness over the years. He sought medical attention because of excessive daytime sleepiness for the last three years.

Physical examination revealed: obesity, increased cervical perimeter, weakness of proximal lim b muscles (MRC grade 4) and dysmorphic abnormalities (micrognathia, re trognathia, clinodactyly of fourth and fifth fingers, short stature, arched palate and thoracic scoliosis, Fig 1A). Potassium level was normal in the inter-attack period and during spontaneous attacks. Electro $c$ a rdiog ram demonstrated sporadic and isolated ventricular ectopy and prolonged QT interval (QTc $=490 \mathrm{~ms})$. Nerve conduction studies and electromyography were normal with no myotonia. An abnormal electrophysiological exercise test confirmed the diagnosis of PP, showing a $61.8 \%$ decrement of compound muscle action potential (CMAP) amplitudes.

Polysomnography showed apnea-hypopnea index (AHI) of 80.2 events/hour, severe oxyhemoglobin desaturation and periods of ventricular bigeminy (Fig 1B).

Detection of a previously described mutation in KCNJ2 (R218W) confirmed the diagnosis of AS. No other mutation was found by sequencing the entire $K C N J 2$ gene. Clinical and genetic evaluation of six family members demonstrated that four had dysmorphic abnormalities but none had PP or cardiac arrhythmia (Fig 1C). The R218W mutation was only found in the 6-year-old daughter, who presented dysmorphic abnormalities (micrognathia, clinodactyly of fourth and fifth fingers, short stature) and OSA (AHI=5.2 events/ hour, mild oxyhemoglobin desaturation). The other three relatives had only a fifth finger clinodactyly.

PP was initially treated with carbonic anhidrase inhibitors (acetazolamide or dichlorphenamide) with decre ase in frequency of episodes of weakness but had to be discontinued due to urinary lithiasis. A moderate control of attacks was achieved with thiazide treatment. After continuous positive airway pressure(CPAP), polysomnography demonstrated an improvement of parameters ( $\mathrm{AHI}=16$ events/hour,
A
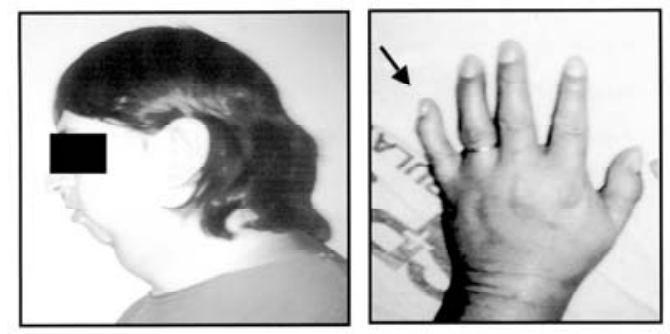

B

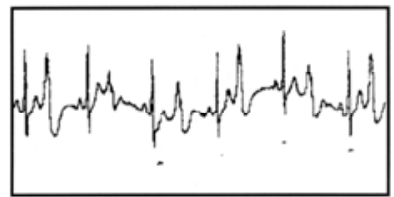

C

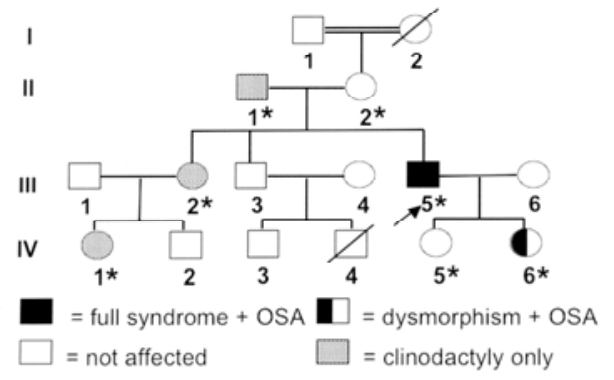

Fig 1. Main findings in the patient with Andersen syndrome and obstructive sleep apnea: (A) The patient presented several dys morphic features, which included facial dysmorphism (microg nathia and retrognathia) and clinodactyly. (B) Electrocardiogram re co rding during polysomnography demonstrated an episode of ventricular bigeminy. (C) The pedigree shows the subjects evaluated in this study (*). A KCNJ2 (R218W) was found in the index patient (III-5) and his daughter (IV-5), both with severe facial dysmorphic abnormalities, which probably induced the development of OSA. Clinodactyly of the fifth finger was observ ed in the two affected subjects, but was also present in 3 oth ers subjects (II-1, III-2, IV-1) not carrying the R218W mutation.

mild oxyhemoglobin desaturation) and no cardiac arrhythmia was detected.

This study was approved by the Ethics Committee of the Universidade Federal de São Paulo. All participants signed informed written consent for the research protocols.

\section{DISCUSSION}

Although the association of PP, extrasystoles and multiple developmental anomalies was first reported in 19717, only recently this triad of manifestations was recognized as a distinct syndrome and named $\mathrm{AS}^{8}$. Diagnosis of AS may be difficult due to the great variability in clinical presentation. Moreover the full syndrome is not always present ${ }^{9}$ like in the daughter's patient, who had only dysmorphic features with- 
out PP or cardiac abnormalities. A previous study demonstrated that only $58 \%$ of $K C N J 2$ mutation carriers presented the full clinical triad while $5 \%$ were nonpenentrant ${ }^{10}$. The same study showed that ventricular arrhythmias were frequent (64\%), syncope and cardiac arrest were reported but no individuals suffered sudden cardiac death ${ }^{10}$.

PP may be associated with hypokalemia, hyperkalemia or normokalemia in AS. The type of PP is defined according to the levels of serum potassium during crises and characteristics of episodic weakness; the hypokalemic form is usually provoked by high carbohydrate intake while the hyperkalemic by fasting or potassium intake.

Abn ormalities in serum potassium levels are only found during attacks, so in the inter-attack period diagnosis relies on clinical features, provocative tests or electrophysiological exercise test. Provocative tests a re not recommended in AS patients due to the risk of induction of arrh $y \mathrm{th} \mathrm{m}$ i a s ${ }^{9}$. Regardless of the type of PP, the diagnosis can be done by an electrophysiological exercise test that typically demonstrates a pronounced decrement $(>40 \%)$ of CMAP amplitude ${ }^{11}$.

Due to the great variability on clinical presenta tion of affected individuals, the diagnosis of AS is established in the presence of two of the following three features: (1) PP; (2) KCNJ2 mutation with electroca rdiographic abnormalities (enlarged U-waves, ventricular ectopy, nonsustained ventricular tachycardia or a prolonged QTc interval); (3) characteristic physical features (at least two of the following: low-set ears, ocular hypertelorism, small mandible, fifth digit clinodactyly and syndactyly). A patient with only one of the features above can be diagnosed with AS when there is one family member with established diagnosis according to the criteria above $e^{8-10,12}$. Our patient and her daughter had manifestations that fulfilled these criteria but the other three relatives did not and hence could not be considered as clinically affected, although clinodactyly is one of the most common dysmorphic features in AS patients ${ }^{12}$. After sequencing the entire $K C N J 2$ gene we excluded that abnormalities in $K C N J 2$ would be responsible for the development of clinodactyly. Another gene may be responsible for this feature.
Although our patient presented the full syndrome, he only sought medical attention because of a symptom not typically related to the disease: excessive daytime sleepiness due to OSA. He was first evaluated in the sleep disorders clinic and had two wellknown and frequent factors predisposing to OSA, obesity and craniofacial abnormalities ${ }^{13}$. Were his manifestations of PP not clear or not well investigated the diagnosis of AS would probably be missed and the patient would be considered as having only OSA due to obesity and craniofacial abnormalities.

The association of AS and OSA was not reported before, but one should keep in mind that patients with craniofacial abnormalities and ventricular arrhythmia during OSA could point out to a mildly affected individual with AS or individuals with the incomplete syndrome.

\section{REFERENCES}

1. Venance SL, Cannon SC, Fialho D, et al. The primary periodic paralyses: diagnosis, pathogenesis and treatment. Brain 2006;129:8-17.

2. Ptacek U, George AL Jr, Griggs RC, et al. Identification of a mutation in the gene causing hyperkalemic periodic paralysis. Cell 1991;67:10211027.

3. Rojas CV, Wang JZ, Schwartz LS, Hoffman EP, Powell BR, Brown RH Jr. A Met-to- Val mutation in the skeletal muscle $\mathrm{Na}+$ channel alphasubunit in hyperkalaemic periodic paralysis. Nature 1991;354:387-389.

4. Ptacek U, Tawil R, Griggs RC, et al. Dihydropyridine receptor mutations cause hypokalemic periodic paralysis. Cell 1994;77:863-868.

5. Jurkat-Rott K, Lehmann-Horn F, Elbaz A, et al. A calcium channel mutation causing hypokalemic periodic paralysis. Hum Mol Genet 1994;3: 1415-1419.

6. Plaster NM, Tawil R, Tristani-Firauzi M, et al. Mutations in Kir2.1 cause the developmental and episodic electrical phenotypes of Andersen's syndrome. Cell 2001;105:511-519.

7. Andersen EA, Krasilnikoff PA, Overvad H. Intermittent muscular weakness, extrasystoles, and multiple developmental anomalies: a new syndrome? Acta Paediatr Scand 1971;60:559-564.

8. Tawil R, Ptacek U, Pavlakis SG, et al. Andersen's syndrome: potassium-sensitive periodic paralysis, ventricular ectopy, and dysmorphic features. Ann Neurol 1994;35:326-330.

9. Sansone V, Griggs RC, Meola G, et al. Andersen's syndrome: a distinct periodic paralysis. Ann Neurol 1997;42:305-312.

10. Tristani-Firouzi M, Jensen JL, Donaldson MR, et al. Functional and clinical) characterization of KCNJ2 mutations associated with LQT7 (Andersen syndrome). J Clin Invest 2002;110:381-388.

11. McManis PO, Lambert EH, Daube JR. The exercise test in periodic paralysis. Muscle Nerve 1986;9:704-710.

12. Donaldson MR, Yoon G, Fu Y-H, Ptacek U. Andersen-Tawil syndrome: a model of clinical variability, pleiotropy, and genetic heterogeneity. Ann Med 2004;36:92-97.

13. F e rguson KA, Ono T, Lowe AA, Ryan CF, Fleetham JA. The relationship between obesity and craniofacial structure in obstructive sleep apnea. Chest 1995;108:375-381. 
This article has received corrections in agreement with the ERRATUM published in Volume 64 Number 4. 